\title{
ERRATUM
}

Feilim Murphy $\cdot$ Prem Puri

\section{New insights into the pathogenesis of Hirschsprung's associated enterocolitis}

Published online: 17 November 2005

(C) Springer-Verlag 2005

\section{Pediatr Surg Int (2005). DOI: 10.007/s00383-005-}

1557-1

This article was mistakenly published as an Original Article. In fact, it is a Review Article.

The online version of the original article can be found at http://dx.doi.org/10.007/s00383-005-1557-1

F. Murphy · P. Puri $(\bowtie)$

The Children's Research Centre, Our Lady's Hospital for Sick,

Children Crumlin, University College Dublin, Dublin 12, Ireland

E-mail: prem.puri@ucd.ic 